\title{
Serological, parasitological and molecular tests for canine visceral leishmaniosis diagnosis in a longitudinal study
}

\author{
Testes sorológicos, parasitológicos e moleculares para o diagnóstico da \\ leishmaniose visceral canina em estudo longitudinal \\ Marcia Dalastra Laurenti ${ }^{6}$; Marcelo Nascimento Burattini ${ }^{6}$ \\ ${ }^{1}$ Faculdade de Medicina Veterinária, Universidade Estadual Paulista - UNESP, Araçatuba, SP, Brasil \\ ${ }^{2}$ Autonomous Veterinarian, São Paulo, SP, Brasil \\ ${ }^{3}$ Companhia Integrada de Desenvolvimento Agrícola de Santa Catarina, Florianópolis, SC, Brasil \\ ${ }^{4}$ Instituto de Ciências Biomédicas, Universidade de São Paulo - USP, São Paulo, SP, Brasil \\ ${ }^{5}$ Instituto Adolfo Lutz - IAL, São Paulo, SP, Brasil \\ ${ }^{6}$ Faculdade de Medicina, Universidade de São Paulo - USP, São Paulo, SP, Brasil
}

Cáris Maroni Nunes ${ }^{1 *}$; Valéria Marçal Félix de Lima ${ }^{1}$; Guilherme Dias de Melo ${ }^{1}$; Henrique Borges de Paula ${ }^{2}$; Maria Esther Gonçalves Pereira ${ }^{3}$; Cristiana de Melo Trinconi Tronco ${ }^{4}$; Roberto Mitsuyoshi Hiramoto ${ }^{5}$;

Received May 5, 2015

Accepted September 14, 2015

\begin{abstract}
One of the measures to control visceral leishmaniosis (VL) in Brazil is the identification and culling of the canine reservoir. There is much controversy concerning this strategy, including the proper identification of positive dogs and the fact that the host-parasite relationship changes over time make it more challenging. A dynamic cohort of 62 dogs was followed every three months using serological and parasitological examinations and PCR. Positivity by PCR was higher than by serology and by parasitological examinations and showed a tendency to decrease over time, while serology tended to increase after six months. Concomitant positivity in all tests was observed in $10.4 \%$ of the samples, and negativity in $29.1 \%$. Overall sensitivity ranged from 43.6 to $64.1 \%$, and was not uniform over time. The proportion of dogs with or without clinical signs was not different by cytology or PCR but PCR was able to identify a larger number of asymptomatic dogs compared to ELISA and immunochromatography. PCR can be useful for surveillance of areas where cases of canine VL have not yet been detected and in which control strategies can be implemented to limit the spread of the disease. Despite the advance in diagnostic tools CVL diagnosis remains a challenge.
\end{abstract}

Keywords: Cohort studies, diagnosis, Leishmania infantum chagasi, parasitological evaluation, PCR, serology.

\section{Resumo}

Uma das medidas de controle da leishmaniose visceral (LV) no Brasil se baseia na identificação e eliminação do reservatório canino. Existe considerável controvérsia relativa a esta estratégia incluindo a correta identificação dos cães positivos e a variação temporal da relação hospedeiro-parasita, o que torna esta medida ainda mais desafiadora. Uma coorte dinâmica de 62 cáes foi acompanhada trimestralmente utilizando-se métodos sorológicos, parasitológicos e a PCR. A taxa de positividade por PCR foi maior em comparação à dos métodos sorológicos e parasitológicos, e mostrou tendência à diminuição com o passar do tempo, enquanto que a positividade sorológica apresentou tendência a aumento, após seis meses. Observou-se positividade concomitante em todos os testes em 10,4\% das amostras e, negatividade concomitante, em 29,1\%. A sensibilidade geral variou de 43,6\% a 64,1\%, não sendo uniforme ao longo do estudo. A proporção de cães com e sem sinais clínicos que foram positivos ao exame parasitológico ou à PCR não foi estatisticamente diferente. Contudo, foi possível identificar como positivos um maior número de animais assintomáticos por meio da técnica de PCR, em comparação aos testes ELISA e imunocromatográfico. A PCR pode ser bastante útil para a vigilância epidemiológica de áreas onde casos de LV canina ainda náo tenham sido descritos e onde estratégias de controle podem ser implantadas para limitar a disseminação da doença. Não obstante o avanço nas ferramentas diagnósticas, diagnosticar a LVC continua um desafio.

Palavras-chave: Estudo coorte, diagnóstico, Leishmania infantum chagasi, avaliação parasitológica, PCR, sorologia.

*Corresponding author: Cáris Maroni Nunes. Departamento de Apoio,

Produção e Saúde Animal, Faculdade de Medicina Veterinária, Universidade

Estadual Paulista "Júlio de Mesquita Filho" - UNESP, Rua Clóvis Pestana, 793,

CEP 16050-680, Araçatuba, SP, Brasil. e-mail: caris@fmva.unesp.br. 


\section{Introduction}

Visceral leishmaniosis (VL) is the most severe form of leishmaniosis, and the domestic dog is the main reservoir for Leishmania infantum (Syn. chagasi), which is transmitted to humans by the sandfly (DESJEUX, 2004). One of the control strategies for VL in Brazil is the serological screening with subsequent culling of seropositive dogs (COSTA \& VIEIRA, 2001; PALATNIK-DE-SOUSA et al., 2001; BRASIL, 2006). This approach has been the object of controversy due to the lack of scientific evidence in reducing the incidence of VL, the variability in the diagnostic techniques used and the long delay between a positive diagnosis and the elimination of the infected dog (COURTENAY et al., 2002; REITHINGER et al., 2002; COSTA, 2011; GRIMALDI et al., 2012a; OTRANTO \& DANTAS-TORRES, 2013).

The characteristics of the diagnostic methods are important parameters for the detection of an infected and infectious dog when selecting a test for use in the large-scale control of infected dogs (QUINNELL et al., 2013). In general, the parasitological examination presents low sensitivity (ALVAR et al., 2004; OLIVA et al., 2006; REIS et al., 2006; LAURENTI, 2009), while PCR has high sensitivity (SOLANO-GALLEGO et al., 2009). Specifically in Brazil, the immunofluorescent-antibody test (IFAT) and the indirect enzyme-linked immunosorbent assay (ELISA) have been widely used for canine visceral leishmaniosis (CVL) mass-screening surveys (GONTIJO \& MELO, 2004; METTLER et al., 2005) until 2012, when a novel immunochromatographic assay (DualPath Platform - $\mathrm{DPP}^{\circ}$ ) was introduced for mass-screening (GRIMALDI et al., 2012b).

The sensitivity of any diagnostic method seems to vary during the course of the disease, as well as among individuals. At the beginning of the infection, before seroconversion or the onset of clinical signs, parasitological examinations and PCR are more sensitive; however, with disease progression, the variation among individuals and their ability to control the disease leads to higher seroconversion and parasitemia, and the detection of positive dogs tends to be best performed by serological and parasitological examinations (QUINNELL et al., 2001; OLIVA et al., 2006).

Culling is compulsory in Brazil as soon as a positive dog is detected (BRASIL, 2006). However, the controversial performance of the diagnostic tests used in mass screening approach has taken place among researchers, veterinarians and the Brazilian Ministry of Health. Therefore, the aim of this study was to contribute to this discussion by testing the performance of four diagnostic techniques (direct parasitological examination, immunochromatography-DPP ${ }^{\circ}$ CVL rapid test, PCR and an in-house indirect ELISA) to identify the canine reservoir of $\mathrm{VL}$, considering the evolution of the disease over time in an urban endemic scenario.

\section{Materials and Methods}

\section{Study area and study design}

This study was conducted in the municipality of Araçatuba, in the state of Sáo Paulo, Brazil (latitude 212' 3" S; longitude 50 5' 58” W), a town with 179,717 inhabitants in 2005 (IBGE, 2013), when the cohort study was conducted (NUNES et al., 2008). The region has a tropical climate with dry winters and rainy summers. In the cold months the average temperature is $18^{\circ} \mathrm{C}$ and in the warmer months is greater than $22^{\circ} \mathrm{C}$ (ROLIM et al., 2007).

Since the identification of VL in the municipality of Araçatuba in 1999, dogs are regularly screened by serology by the municipal Zoonosis Control Center. Positive dogs are euthanized with the owners' permission, in compliance with state law (SÃO PAULO, 2006). As part of VL control measures, vector control based on insecticide spraying was also used in the surround area whenever a human case was confirmed. The dogs included in this dynamic cohort study replaced seropositive dogs that had been previously removed by the Zoonosis Control Center. Once the owners had agreed to take part in the study, visits were scheduled every three months, when data regarding sex, age, breed and the presence of external clinical signs were collected and biological samples were taken (NUNES et al., 2007). Therefore, dogs were included at different times in this study and it was executed during a total of 27 months.

Dogs were resident in the Alvorada neighborhood, which had a CVL prevalence of $10.3 \%$. Most of these dogs' owners did not use any repellent or topic insecticide to prevent sandflies bites (unpublished data).

\section{Sampling and CVL diagnosis}

During each visit, new dogs that had been replaced by the owners were included in this cohort. Thus, to give more consistency to the diagnostic tests performance analysis, we excluded dogs that had less than three samplings in this study. Serum samples were selected using archived material (NUNES et al., 2008) kept at $-80^{\circ} \mathrm{C}$. Serological evaluation was performed by indirect ELISA as described by Lima et al. (2005) and by a quick immunochromatographic assay based on Dual-Path Platform technology $\left(\mathrm{DPP}^{\circ} \mathrm{CVL}\right.$ rapid test, Fiocruz/Bio-Manguinhos Unit, Brazil). DNA was extracted from total blood samples using the phenol/chloroform method and PCR was performed using specific Leishmania primers for kDNA amplification (120bp), as previously described (NUNES et al., 2007). Parasitological examination was also performed using popliteal lymph node fine needle aspiration cytology stained with a quick Romanowsky-type stain (Panótico rápido ${ }^{\circ}$, Laborclin-Brazil). Indirect ELISA and PCR were performed during the collection period (2002-2005) and the immunochromatographic assay (DPP ${ }^{\circ} \mathrm{CVL}$ rapid test) was performed in 2013.

\section{Statistical analysis}

Sensitivity and specificity were calculated using the parasitological evaluation as gold standard and the kappa coefficient $(\kappa)$ was determined in order to evaluate agreement between the tests (CONRATHS \& SCHARES, 2006). Fisher's exact test was used to compare the proportions of CVL positivity by different diagnostic techniques, and also to assess their relationship with the occurrence of clinical signs. 


\section{Ethical issues}

This study was approved by our institution's Ethics and Animal Welfare Committee (CEEA, UNESP; procedural no. 30/04).

\section{Results}

\section{Sampling and diagnostic methods validation}

The dogs were followed up for 27 months, on a quarterly basis, and 10 samplings were performed, totaling 303 biological samples obtained from 62 dogs. However, one limitation of this study was that, due to the refusal of some owners to permit popliteal lymph node aspiration on every visit, the parasitological examination was performed only on 54 dogs, representing 44.2\% (134/303) of the total number of samples.

PCR presented the highest of positivity percentage (46.5\%), followed by parasitological examination $(29.1 \%)$. The serological assays exhibited the lowest percentage of positivity, with $20.5 \%$ for indirect ELISA and $14.5 \%$ for the immunochromatographic assay.

If the parasitological examination is taken to be the gold standard, this means that only 134 samples could be evaluated. Among these, the sensitivity of PCR $(64.1 \%)$ was higher than that of ELISA (43.6\%) and immunochromatography (46.2\%), although its specificity was lower (PCR 61.8\%; ELISA 86.3\%; immunochromatography $88.2 \%$ ). The diagnostic sensitivity of the tests was also calculated for each sampling session (Table 1) and higher values were observed within the first year of the follow-up period. Thereafter, many samples were lost. No significant difference was observed between test sensitivities ( $p>0.05)$. Considering the gold standard and the cumulative results of the four diagnostic methods, concomitant positivity in all tests was observed in only $10.4 \%(14 / 134)$ of the samples, and concomitant negativity in $29.1 \%(39 / 134)$.

\section{CVL diagnosis over time}

Only 4.8\% of the dogs (numbers 4,67 and 70) remained negative in all tests up to the end of the follow-up period. Amastigote forms of Leishmania were detected in the popliteal lymph node cytology of 20 dogs, although $40 \%$ of them (numbers $40,41,42$,
$43,47,65,77$ and 87) did not remain positive in the subsequent sampling session (Figure 1). Among the 23 dogs that presented positive results by the immunochromatographic assay, $26.1 \%$ (numbers 8, 16, 30, 42, 47 and 63) presented seroreversion. Moreover, when assessed by means of ELISA, only two out of the 31 dogs (numbers 51 and 76) presented seroreversion, but they seroconverted in the subsequent evaluations, while $9.7 \%$ (numbers 8, 49 and 53) seroreverted and seroconverted again by the end of the study (Figure 1).

PCR presented rather inconsistent results: out of the 53 positive dogs, 35.8\% (numbers 8, 9, 16, 17, 20, 29, 30, 31, 34, 38, 42, $43,50,52,60,65,76,92$ and 93) presented as seronegative afterwards, and $20.7 \%$ (numbers 5, 11, 18, 25, 26, 41, 45, 49, 57, 62 and 74) presented intermittent results, sometimes positive and sometimes negative (Figure 1).

One difficulty inherent to cohort studies is the loss of individuals over time. One hundred and sixteen dogs had initially been selected for this study but, in addition to the expected loss, dogs were included at different time points, thus resulting in an average follow-up of 12 months. Consequently, few samples were taken in the last sampling sessions, which interfered with the percentage positivity.

\section{Agreement among CVL diagnostic methods}

The strength of agreement between the parasitological examination and the other tests was considered to be fair, whether for immunochromatography $(\kappa=0.371)$, ELISA $(\kappa=0.331)$ or PCR $(\kappa=0.238)$. The serological tests (immunochromatography and ELISA) showed moderate agreement between each other $(\kappa=0.460)$. On the other hand, poor agreement was observed between PCR and immunochromatography $(\kappa=0.097)$ and between PCR and ELISA ( $\kappa=0.186)$.

\section{CVL diagnosis and external clinical signs}

The onset of external clinical signs (cutaneous lesions, lymphadenopathy, onychogryphosis and weight loss) was observed in $46.7 \%$ (29/62) of the dogs during the follow-up period (see time points highlighted in gray in Figure 1). Considering all the time

Table 1. Sensitivity (S) of immunochromatography (DPP), indirect ELISA and PCR for diagnosing visceral leishmaniasis in dogs over time (27 months), taking the parasitological examination as the gold standard. Araçatuba, SP, Brazil.

\begin{tabular}{|c|c|c|c|c|c|c|c|c|}
\hline \multirow{2}{*}{$\begin{array}{c}\text { Follow-up } \\
\text { (months) }\end{array}$} & \multicolumn{2}{|c|}{ lymph node cytology } & \multicolumn{2}{|c|}{ DPP } & \multicolumn{2}{|c|}{ ELISA } & \multicolumn{2}{|c|}{ PCR } \\
\hline & total & positive & n/total & S (\%) & n/total & S (\%) & n/total & S (\%) \\
\hline 0 & 25 & 3 & $0 / 3$ & 0.0 & $0 / 3$ & 0.0 & $0 / 3$ & 0.0 \\
\hline 3 & 28 & 12 & $5 / 12$ & 41.7 & $3 / 12$ & 25.0 & $8 / 12$ & 66.7 \\
\hline 6 & 30 & 9 & $4 / 9$ & 44.4 & $3 / 9$ & 33.3 & $6 / 9$ & 66.7 \\
\hline 9 & 16 & 5 & $3 / 5$ & 60.0 & $3 / 5$ & 60.0 & $2 / 5$ & 40.0 \\
\hline 12 & 18 & 5 & $3 / 5$ & 60.0 & $5 / 5$ & 100.0 & $4 / 5$ & 80.0 \\
\hline 15 & 10 & 2 & $1 / 2$ & 50.0 & $1 / 2$ & 50.0 & $2 / 2$ & 100.0 \\
\hline 18 & 5 & 2 & $1 / 2$ & 50.0 & $1 / 2$ & 50.0 & $2 / 2$ & 100.0 \\
\hline 21 & 0 & 0 & $0 / 0$ & 0.0 & $0 / 0$ & 0.0 & $0 / 0$ & 0.0 \\
\hline 24 & 2 & 1 & $1 / 1$ & 100.0 & $1 / 1$ & 100.0 & $1 / 1$ & 100.0 \\
\hline 27 & 0 & 0 & $0 / 0$ & 0.0 & $0 / 0$ & 0.0 & $0 / 0$ & 0.0 \\
\hline Cumulative & 134 & 39 & $18 / 39$ & 46.2 & $17 / 39$ & 43.6 & $25 / 39$ & 64.1 \\
\hline
\end{tabular}



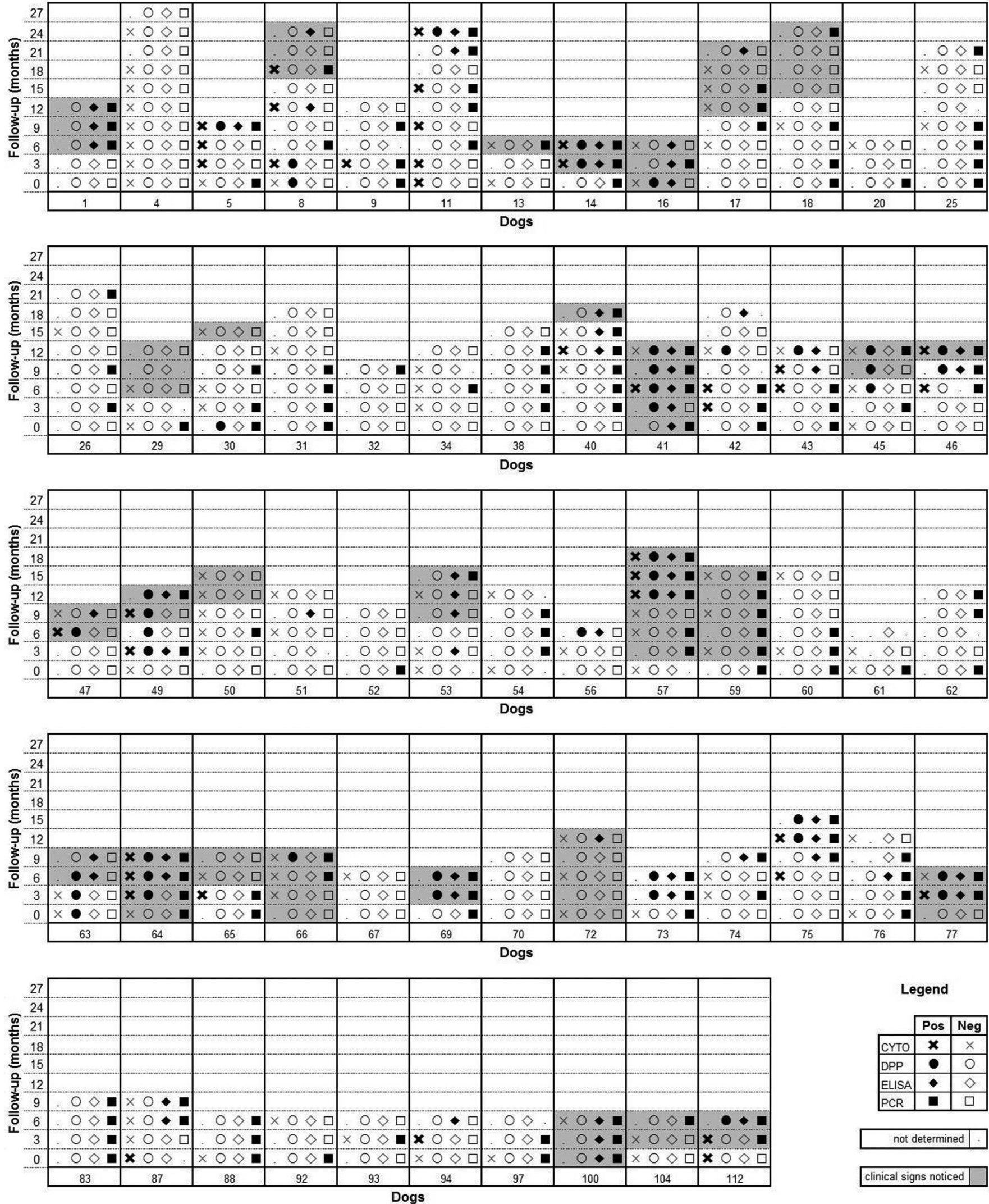

Legend

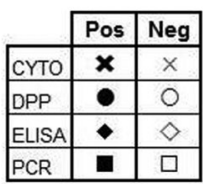

not determined .

clinical signs noticed

Figure 1. Individual results from visceral leishmaniasis diagnosis among $62 \mathrm{dogs}$ from which at least three samplings were possible during the 27 months of the experimental period. Diagnosis was performed every three months by means of popliteal lymph node cytological test (CYTO), immunochromatography (DPP), ELISA and PCR. The time at which the onset of clinical signs was observed is shown on the plot. 
points combined, during the period of observation of the clinical signs, ten dogs were positive by cytology, 14 by DPP, 19 by ELISA and 22 by PCR. Concomitant positivity was verified in $9.6 \%$ of the dogs, whereas concomitant negativity was observed in 6.4\% (Figure 2). Moreover, in five dogs (\#18, 66, 72, 77 and 104), a positive diagnosis by at least one method was achieved only 3 to 12 months after the onset of clinical signs. Despite the presence of clinical signs, cytology was negative in $58.3 \%$ of the dogs over time, whereas DPP was negative in $44.8 \%$; ELISA in $31 \%$, and PCR in $10.3 \%$ of the dogs.

Among the remaining 33 dogs with no clinical signs, eight were positive by cytology, seven by DPP, 12 by ELISA, and 27 were positive by PCR (Figure 2). No difference was determined between the proportions of dogs with or without clinical signs that were positive by cytology ( $\mathrm{p}=0.1806)$ or by PCR $(\mathrm{p}=0.4826)$. However, the proportions of positivity by ELISA $(\mathrm{p}=0.0126)$ and by DPP $(\mathrm{p}=0.0084)$ were higher in dogs with clinical signs.

\section{Discussion}

Sixty-two dogs from an urban area that is endemic for VL were followed up, thus allowing us to observe variations in the CVL diagnosis according to the diagnostic method and disease progression over time. This is an essential difference to similar reports, in which the diagnostic comparison is usually made by cross-sectional studies, evaluating samples taken at only one time point (ASHFORD et al., 1995; SOLANO-GALLEGO et al., 2001; REITHINGER et al., 2002; MOREIRA etal., 2007; FALQUETO etal., 2009; GRIMALDI etal., 2012b; SILVA et al., 2013).

A limited number of longitudinal studies have been conducted in Brazil on cases of naturally infected dogs. These studies involved different designs with different diagnostic techniques (QUINNELL et al., 2001, 2003, 2013; FRANÇA-SILVA et al., 2005; OLIVA et al., 2006; CARSON et al., 2009; GRIMALDI et al., 2012a; COURA-VITAL et al., 2013), and this makes comparisons with the data presented here more difficult.

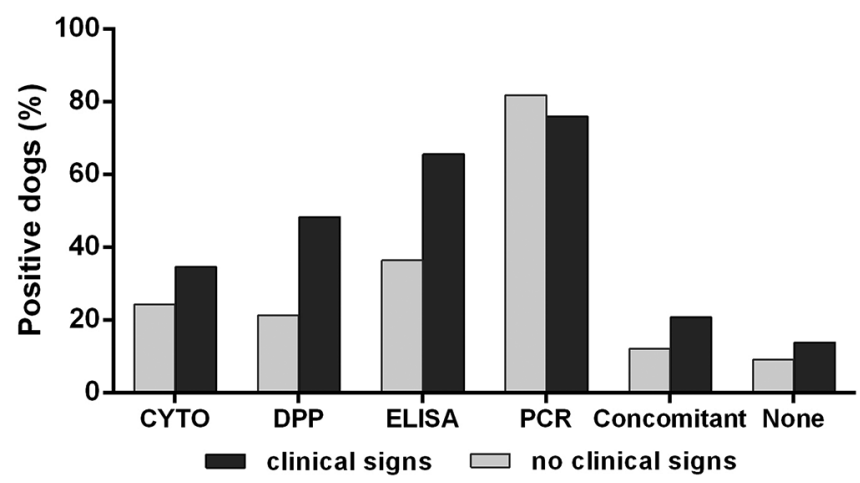

Figure 2. Proportion of dogs positive for visceral leishmaniasis in a 27 months follow-up study according to the occurrence of external clinical signs and according to the diagnostic test: popliteal lymph node cytological test (CYTO), immunochromatography (DPP), ELISA and PCR. "Concomitant" indicates simultaneous positivity in all four diagnostic tests, whereas "None" indicates absence of positive results in all tests. Araçatuba, SP, Brazil.
Overall, we detected low sensitivity ranging from 43.6 to $64.1 \%$. This result may have been an underestimate, because of the low number of samples that we were able to include in this study, the low sensitivity of the parasitological test that was used as the gold standard (MAIA \& CAMPINO, 2008; LAURENTI, 2009), and the complex relationship between Leishmania and the canine host, thus leading to changes to test sensitivity over the clinical course of the disease.

The evolution of CVL is diverse in the population and depends on the host-specific immune response and the parasite's pathogenicity (GRIMALDI et al., 2012a), thus making its diagnosis even more challenging. The sensitivity of a diagnostic technique is very important with regard to detecting the canine VL reservoir (QUINNELL et al., 2013). In our study, PCR on blood samples was seen to have greater sensitivity than the DPP or ELISA tests within the first six months of the follow-up period (Table 1). This was possibly because the dogs may have only recently been infected, since the owners had replaced them within the last four months (NUNES et al., 2008), but it is more likely to have been influenced by the sample size. Although blood samples might not be the best biological sample for detecting DNA by PCR, blood collection is less invasive and it can be a useful approach when dogs have just been introduced into an area, resulting in early detection of the canine reservoir. Nevertheless, although PCR techniques are fast, expertise and equipment are required for them to be performed, thus restricting their mass use in developing countries.

After six months of follow-up, the serological tests (DPP or ELISA) obtained higher sensitivity values in our study. Furthermore, among dogs with a positive VL diagnosis, only $16.1 \%$ presented reversion of positivity according to ELISA and $26.1 \%$ as seen on immunochromatography. On the other hand, PCR showed that positivity was reverted in $35.8 \%$, thus suggesting that despite its high sensitivity, positive results are more consistent when using serological evaluation than when using PCR performed on blood samples. Oliva et al. (2006) also observed several cases of dogs found to be positive by nested-PCR that were negative by other tests, but most of the dogs remained negative until the end of the study (32 months). Another follow-up study conducted in Italy also detected high variability among the diagnostic techniques over time among naturally infected dogs (PARADIES et al., 2010). Grimaldi et al. (2012a) observed similar sensitivity for the DPP test $(47 \%)$, but their reversion rate was also higher (50\%), either because they used a different sample (whole blood instead of serum) or because the dogs surveyed could be more resistant to infection.

Rapid tests like DPP are practical and can be performed at the owners' home when using whole blood, thus giving the owners the chance to actually see the results. However, the Brazilian Ministry of Health currently recommends its use with serum samples. Thus, DPP is performed in a laboratory and positivity is confirmed by means of an ELISA test (EIE-Bio-Manguinhos ${ }^{\circledR}$ ) in order to ensure greater sensitivity and specificity (ARRUDA et al., 2013). Silva et al. (2013) observed greater sensitivity for DPP (93\%) than was seen from the data presented herein. However, their data were derived from only one time point, while ours were based on a longitudinal study, in which positivity was influenced by the course of the disease. 
The ELISA and DPP tests more readily detected symptomatic positive dogs than asymptomatic ones. It is widely agreed that immunity against VL depends on how the host responds to the infection, either by a Th 1 or Th 2 immune response. Symptomatic dogs tend to mount a Th2 response, leading to a B-cell polyclonal activity and then to hypergammaglobulinemia (BARBIÉRI, 2006; REIS et al., 2009). Since these serological assays detect IgG, it is more likely that they will detect symptomatic than asymptomatic dogs, in contrast to PCR or cytological tests, which detect the parasite itself.

Forty percent of the parasitologically positive dogs turned out to be negative in the following evaluations. This could be due to the parasite distribution within the host, thereby leading to low diagnostic sensitivity, or it could be due to the recovering from infection. In fact, two of the parasitologically positive dogs (numbers 42 and 47) showed seroconversion according to DPP and two (numbers 42 and 43) turned out to be PCR-negative over time (Figure 1). Detection of the canine reservoir by PCR also showed a proportion of dogs $(35.8 \%)$ that later on presented as seronegative and, although technical flaws may have influenced this result, a considerable number of dogs may have cleared the infection, as previously postulated by Dye (1996). However, when PCR presents greater positivity than the gold standard test, a decrease in specificity may occur, and vice versa (CONRATHS \& SCHARES, 2006), as observed in our study.

Regarding the ELISA test, the lower sensitivity (43.6\%) and specificity $(86.3 \%)$ observed in our study, in comparison with others (QUINNELL et al., 1997, 2001; REITHINGER et al., 2002; ALMEIDA et al., 2005; ROSÁRIO et al., 2005), may have been because we included all the samples collected over the entire period and not just single samplings. Methodological differences, such as the antigen and reagents used, are likely to have contributed to this difference as well. Similarly, immunochromatography presented lower sensitivity in dogs with or without clinical signs, in comparison to the data reported by Grimaldi et al. (2012b).

The relationship between infection and serological data changes during the course of the disease (QUINNELL et al., 1997) resulting in variation in the percentage of positivity, as well as the sensitivity of each diagnostic technique. At the beginning, parasitological examinations and PCR are more sensitive; with the evolution of the infection, symptomatic dogs present an increase in serum antibody levels and parasite load (QUINNELL et al., 2001, 2003). In our study, despite the effect of the sample size, this effect was observed, with greater positivity according to parasitological examinations and PCR in the first nine months, which subsequently decreased. In contrast, ELISA and immunochromatography showed low positivity at the beginning, with a gradual increase until a maximum peak of positivity at 12 months, which later decreased. Furthermore, PCR was able to identify a larger number of asymptomatic dogs, in comparison to immunochromatography and ELISA. It may provide a useful diagnostic test when considering surveillance in areas where cases of CVL have not yet been detected and in which control strategies can be implemented, thus limiting the spread of the disease.

One of the limitations of our study is that although the total follow-up period was considerable (27 months), the period that each individual dog was followed up was variable and occasionally was less than six months. Despite this, we were able to confirm that positivity for CVL varied depending on the diagnostic technique and on the evolution of the disease. In general, the serological evaluation by means of immunochromatography and ELISA showed greater potential for mass-screening identification of infected dogs in endemic areas, although more than one test should be performed in order to ensure proper identification of the canine reservoir. Despite the advance in diagnostic tools, diagnosing canine VL remains a challenge.

\section{References}

Almeida MAO, Jesus EEV, Sousa-Atta MLB, Alves LC, Berne MEA, Atta AM. Clinical and serological aspects of visceral leishmaniasis in Northeast Brazilian dogs naturally infected with Leishmania chagasi. Vet Parasitol 2005; 127(3-4): 227-232. http://dx.doi.org/10.1016/j. vetpar.2004.10.010. PMid:15710523.

Alvar J, Cañavate C, Molina R, Moreno J, Nieto J. Canine leishmaniasis. Adv Parasitol 2004; 57: 1-88. http://dx.doi.org/10.1016/S0065308X(04)57001-X. PMid:15504537.

Arruda MM, Figueiredo FB, Cardoso FA, Hiamamoto RM, Brazuna JCM, Oliveira MRF, et al. Validity and reliability of enzyme immunoassays using Leishmania major or L. infantum antigens for the diagnosis of canine visceral leishmaniasis in Brazil. PLoS One 2013; 8(7): e69988. http:// dx.doi.org/10.1371/journal.pone.0069988. PMid:23922884.

Ashford DA, Bozza M, Freire M, Miranda JC, Sherlock I, Eulalio $\mathrm{C}$, et al. Comparison of the polymerase chain reaction and serology for the detection of canine visceral leishmaniasis. Am J Trop Med Hyg 1995; 53(3): 251-255. PMid:7573707.

Barbiéri CL. Immunology of canine leishmaniasis. Parasite Immunol 2006; 28(7): 329-337. http://dx.doi.org/10.1111/j.1365-3024.2006.00840.x. PMid:16842269.

Brasil. Ministério da Saúde, Secretaria de Vigilância em Saúde. Manual de vigilância e controle da leishmaniose visceral. Brasília: Editora do Ministério da Saúde; 2006.

Carson C, Antoniou M, Christodoulou V, Messaritakis I, Quinnell RJ, Blackwell JM, et al. Selection of appropriate serological tests to measure the incidence of natural Leishmania infantum infection during DNA/ MVA prime/boost canine vaccine trials. Vet Parasitol 2009; 162(3-4): $207-$ 213. http://dx.doi.org/10.1016/j.vetpar.2009.03.037. PMid:19386420.

Conraths F, Schares G. Validation of molecular-diagnostic techniques in the parasitological laboratory. Vet Parasitol 2006; 136(2): 91-98. http:// dx.doi.org/10.1016/j.vetpar.2005.12.004. PMid:16414191.

Costa CH, Vieira JB. Mudanças no controle da leishmaniose visceral no Brasil. Rev Soc Bras Med Trop 2001; 34(2): 223-228. http://dx.doi. org/10.1590/S0037-86822001000200013. PMid:11391448.

Costa CHN. How effective is dog culling in controlling zoonotic visceral leishmaniasis? A critical evaluation of the science politics and ethics behind this public health policy. Rev Soc Bras Med Trop 2011; 44(2): 232-242. http://dx.doi.org/10.1590/S0037-86822011005000014. PMid:21468480.

Coura-Vital W, Reis AB, Reis LES, Braga SL, Roatt BM, Aguiar-Soares $\mathrm{RDO}$, et al. Canine visceral leishmaniasis: incidence and risk factors for infection in a cohort study in Brazil. Vet Parasitol 2013; 197(3-4): 411417. http://dx.doi.org/10.1016/j.vetpar.2013.07.031. PMid:23941965. 
Courtenay O, Quinnell RJ, Garcez LM, Shaw JJ, Dye C. Infectiousness in a cohort of Brazilian dogs: why culling fails to control visceral leishmaniasis in areas of high transmission. J Infect Dis 2002; 186(9): 1314-1320. http://dx.doi.org/10.1086/344312. PMid:12402201.

Desjeux P. Leishmaniasis: current situation and new perspectives. Comp Immunol Microbiol Infect Dis 2004; 27(5): 305-318. http://dx.doi. org/10.1016/j.cimid.2004.03.004. PMid:15225981.

Dye C. The logic of visceral leishmaniasis control. Am J Trop Med Hyg 1996; 55(2): 125-130. PMid:8780448.

Falqueto A, Ferreira AL, Santos CB, Porrozzi R, Costa MVS, Teva A, et al. Cross- sectional and longitudinal epidemiologic surveys of human and canine Leishmania infantum visceral infections in an endemic rural area of southeast Brazil (Pancas, Espírito Santo). Am J Trop Med Hyg 2009; 80(4): 559-565. PMid:19346375.

França-Silva JC, Barata RA, Costa RT, Monteiro EM, Machado-Coelho GLL, Vieira EP, et al. Importance of Lutzomyia longipalpis in the dynamics of transmission of canine visceral leishmaniasis in the endemic area of Porteirinha municipality, Minas Gerais, Brazil. Vet Parasitol 2005; 131(3-4): 213-220. http://dx.doi.org/10.1016/j.vetpar.2005.05.006. PMid:15975718.

Gontijo CMF, Melo MN. Leishmaniose visceral no Brasil: quadro atual, desafios e perspectivas. Rev Bras Epidemiol 2004; 7(3): 338-349. http:// dx.doi.org/10.1590/S1415-790X2004000300011.

Grimaldi G Jr, Teva A, Ferreira AL, Santos CB, Falqueto A. The effect of removing potentially infectious dogs on the numbers of canine Leishmania infantum infections in an endemic area with high transmission rates. Am J Trop Med Hyg 2012a; 86(6): 966-971. http://dx.doi.org/10.4269/ ajtmh.2012.12-0040. PMid:22665602.

Grimaldi G Jr, Teva A, Ferreira AL, Santos CB, Pinto IS, Azevedo CT, et al. Evaluation of a novel chromatographic immunoassay based on Dual-Path Platform technology (DPP ${ }^{\circledR}$ CVL rapid test) for the serodiagnosis of canine visceral leishmaniasis. Trans R Soc Trop Med Hyg 2012b; 106(1): 54-59. http://dx.doi.org/10.1016/j.trstmh.2011.10.001. PMid:22137538.

Instituto Brasileiro de Geografia e Estatística - IBGE. Estimativas populacionais para os municipios brasileiros em 01.07.2013. Epi Info [online]. Brasília; 2013 [cited 2013 Nov 5]. Available from: http://www. ibge.gov.br/home/estatistica/populacao/estimativa2013

Laurenti MD. Correlation between parasitological and serological diagnosis in canine American visceral leishmaniasis. Bol Epidemiol Paul 2009; 6(67): 13-23.

Lima VMF, Biazzono L, Silva AC, Correa APFL, Luvizotto MCR. Serological diagnosis of visceral leishmaniasis by an enzyme immunoassay using protein A in naturally infected dogs. Pesqui Vet Bras 2005; 25(4): 215-218. http://dx.doi.org/10.1590/S0100-736X2005000400005.

Maia C, Campino L. Methods for diagnosis of canine leishmaniasis and immune response to infection. Vet Parasitol 2008; 158(4): 274-287. http:// dx.doi.org/10.1016/j.vetpar.2008.07.028. PMid:18789583.

Mettler M, Grimm F, Capelli G, Camp H, Deplazes P. Evaluation of enzyme-linked immunosorbent assays, an immunofluorescent-antibody test, and two rapid tests (immunochromatographic-dipstick and gel tests) for serological diagnosis of symptomatic and asymptomatic Leishmania infections in dogs. J Clin Microbiol 2005; 43(11): 5515-5519. http:// dx.doi.org/10.1128/JCM.43.11.5515-5519.2005. PMid:16272479.

Moreira MAB, Luvizotto MCR, Garcia JF, Corbett CEP, Laurenti MD. Comparison of parasitological, immunological and molecular methods for the diagnosis of leishmaniasis in dogs with different clinical signs.
Vet Parasitol 2007; 145(3-4): 245-252. http://dx.doi.org/10.1016/j. vetpar.2006.12.012. PMid:17257764.

Nunes CM, Dias AK, Gottardi FP, Paula HB, Azevedo MAA, Lima VMF, et al. Avaliaçáo da reação em cadeia pela polimerase para diagnóstico da leishmaniose visceral em sangue de cães. Rev Bras Parasitol Vet 2007; 16(1): 5-9. PMid:17588315.

Nunes CM, Lima VMF, Paula HB, Perri SHV, Andrade AM, Dias FEF, et al. Dog culling and replacement in an area endemic for visceral leishmaniasis in Brazil. Vet Parasitol 2008; 153(1-2): 19-23. http://dx.doi. org/10.1016/j.vetpar.2008.01.005. PMid:18314275.

Oliva G, Scalone A, Foglia Manzillo V, Gramiccia M, Pagano A, Di Muccio $\mathrm{T}$, et al. Incidence and time course of Leishmania infantum infections examined by parasitological, serologic and nested-PCR techniques in a cohort of naive dogs exposed to three consecutive transmission seasons. J Clin Microbiol 2006; 44(4): 1318-1322. http://dx.doi.org/10.1128/ JCM.44.4.1318-1322.2006. PMid:16597857.

Otranto D, Dantas-Torres F. The prevention of canine leishmaniasis and its impact on public health. Trends Parasitol 2013; 29(7):339-345. http:// dx.doi.org/10.1016/j.pt.2013.05.003. PMid:23746747.

Palatnik-de-Sousa CB, Santos WR, França-Silva JC, Costa RT, Reis $\mathrm{AB}$, Palatnik $\mathrm{M}$, et al. Impact of canine control on the epidemiology of canine and human visceral leishmaniasis in Brazil. Am J Trop Med Hyg 2001; 65(5): 510-517. PMid:11716106.

Paradies P, Sasanelli M, Caprariis D, Testini G, Traversa D, Lia RP, et al. Clinical and laboratory monitoring of dogs naturally infected by Leishmania infantum. Vet J 2010; 186(3): 370-373. http://dx.doi.org/10.1016/j. tvjl.2009.09.011. PMid:19836279.

Quinnell RJ, Carson C, Reithinger R, Garcez LM, Courtenay O. Evaluation of rk39 rapid diagnostic test for canine visceral leishmaniasis: longitudinal study and meta- analysis. PLoS Negl Trop Dis 2013; 7(1): e1992. http:// dx.doi.org/10.1371/journal.pntd.0001992. PMid:23326615.

Quinnell RJ, Courtenay O, Davidson S, Garcez L, Lambson B, Ramos P, et al. Detection of Leishmania infantum by PCR, serology and cellular immune response in a cohort study of Brazilian dogs. Parasitology 2001; 122(3): 253-261. http://dx.doi.org/10.1017/S0031182001007363. PMid:11289062.

Quinnell RJ, Courtenay O, Garcez L, Dye C. The epidemiology of canine leishmaniasis: transmission rates estimated from a cohort study in Amazonian Brazil. Parasitology 1997; 115(2): 143-156. http://dx.doi. org/10.1017/S0031182097001200. PMid:10190170.

Quinnell RJ, Courtenay O, Garcez LM, Kaye PM, Shaw MA, Dye $\mathrm{C}$, et al. IgG subclass responses in a longitudinal study of canine visceral leishmaniasis. Vet Immunol Immunopathol 2003; 91(3-4): 161-168. PMid:12586479.

Reis AB, Martins-Filho OA, Teixeira-Carvalho A, Carvalho MG, Mayrink W, França-Silva JC, et al. Parasite density and impaired biochemical/ hematological status are associated with severe clinical aspects of canine visceral leishmaniasis. Res Vet Sci 2006; 81(1): 68-75. http://dx.doi. org/10.1016/j.rvsc.2005.09.011. PMid:16288789.

Reis AB, Martins-Filho OA, Teixeira-Carvalho A, Giunchetti RC, Carneiro $\mathrm{CM}$, Mayrink W, et al. Systemic and compartmentalized immune response in canine visceral leishmaniasis. Vet Immunol Immunopathol 2009; 128(1-3): 87-95. http://dx.doi.org/10.1016/j.vetimm.2008.10.307. PMid:19054576.

Reithinger R, Quinnell RJ, Alexander B, Davies CR. Rapid detection of Leishmania infantum infection in dogs: comparative study using an 
immunochromatographic dipstick test, enzyme-linked immunosorbent assay, and PCR. JClin Microbiol 2002; 40(7): 2352-2356. http://dx.doi. org/10.1128/JCM.40.7.2352-2356.2002. PMid:12089247.

Rolim GS, Camargo MBP, Lania DG, Moraes JFL. Classificação climática de Köppen e de Thornthwaite e sua aplicabilidade na determinação de zonas agroclimáticas para o Estado de São Paulo. Bragantia 2007; 66(4): 711-720. http://dx.doi.org/10.1590/S0006-87052007000400022.

Rosário EY, Genaro O, França-Silva JC, Costa RT, Mayrink W, Reis $\mathrm{AB}$, et al. Evaluation of enzyme-linked immunosorbent assay using crude Leishmania and recombinant antigens as a diagnostic marker for canine visceral leishmaniasis. Mem Inst Oswaldo Cruz 2005; 100(2): 197-203. http://dx.doi.org/10.1590/S0074-02762005000200015. PMid:16021309.

São Paulo. Secretaria de Estado da Saúde de São Paulo - SES-SP, Superintendência de Controle de Endemias - SUCEN, Coordenadoria de Controle de Doenças - CCD. Manual de vigilância e controle da leishmaniose visceral americana do Estado de São Paulo. São Paulo; 2006.

Silva DA, Madeira MF, Abrantes TR, Barbosa-Filho CJL, Figueiredo FB. Assessment of serological tests for the diagnosis of canine visceral leishmaniasis. Vet J2013; 195(2): 252-253. http://dx.doi.org/10.1016/j. tvjl.2012.06.010. PMid:22789627.

Solano-Gallego L, Koutinas A, Miró G, Cardoso L, Pennisi MG, Ferrer $\mathrm{L}$, et al. Directions for the diagnosis, clinical staging, treatment and prevention of canine leishmaniosis. Vet Parasitol 2009; 165(1-2): 1-18. http://dx.doi.org/10.1016/j.vetpar.2009.05.022. PMid:19559536.

Solano-Gallego L, Morell P, Arboix M, Alberola J, Ferrer L. Prevalence of Leishmania infantum infection in dogs living in an area of canine leishmaniasis endemicity using PCR on several tissues and serology. J Clin Microbiol 2001; 39(2): 560-563. http://dx.doi.org/10.1128/ JCM.39.2.560-563.2001. PMid:11158106. 